DOI https://doi.org/10.30525/978-9934-588-92-1-30

\title{
ПОРІВНЯЛЬНО-ПРАВОВИЙ АНАЛІЗ ЗАХИСТУ ЕКОЛОГІЧНИХ ПРАВ ЛЮДИНИ В УКРАЇНІ ТА РЕСПУБЛІЦІ ПОЛЬЩА
}

\author{
Толкачова I. А. \\ кандидат юридичних наук, \\ доцент кафедри конституційного і адміністративного права \\ Національного авіачійного університету \\ Кириченко В. В. \\ студентка юридичного факультету \\ Начіонального авіачійного університету \\ м. Київ, Украӥна
}

Сучасні виклики та процеси глобалізації вимагають створення нової суспільної свідомості й потребують суттєвих змін в політиці та економіці світового співтовариства. Однак, реалізація таких прагнень неможлива без дотримання екологічних прав людини. Станом на сьогодні, екологічні права залишаються в центрі уваги розвинених держав світу. Цей напрям захисту прав людини досить мало закріплений в конституціях країн, а право на безпечне навколишнє середовище взагалі не вказане в жодному міжнародному акті. Реальне дотримання екологічних прав людини та наявність дієвих механізмів його захисту є показником того, наскільки розвиток держави відповідає сучасним потребам суспільства.

Україна доволі стрімко інтегрується в європейський простір, та спрямовує свою діяльність на створення правової держави, повинна забезпечувати своїм громадянам реалізацію та захист екологічних прав. Стратегічним партнером України у формуванні транскордонної i регіональної екологічної політики є Республіка Польща [1, с. 7].

Статею 50 Конституції України громадянам гарантується, що кожен має право на безпечне для життя і здоров'я довкілля та на відшкодування завданої порушенням цього права шкоди [2]. Ще одним джерелом нормативного забезпечення реалізації екологічних прав людини в Україні $є$ Закон України «Про охорону навколишнього природного середовища» [3] (далі - Закон). В даному нормативноправовому акті зазначений як перелік екологічних прав громадян України, так і гарантії їх захисту. 
Окрім закріплення екологічних прав та гарантій важливою $\epsilon$ можливість доступу громадян до правосуддя у сфері екології. У випадку необхідості захисту свого екологічного права в суді, громадяни України стикаються із рядом проблем, які пов'язані 3 відсутністю спеціалізованого екологічного правосуддя в державі. Справа в тому, що знання в екологічному праві базуються не лише на юриспруденції, а й на знаннях з екології безпосередньо. Таким чином, однією з найважливіших проблем в екологічному судочинстві України $€$ недостатня обізнаність суддів у галузі охорони довкілля та відсутність можливості отримати кваліфіковану правову допомогу. Такі проблеми є свідченням того, що екологічне право та екологічне судочинство $є$ недостатньо розвиненими в Україні.

Цінним джерелом для подальшого розвитку екологічного судочинства в Україні $є$ практика Європейського суду з прав людини (далі - ЄСПЛ), адже вона стосуються проблем в нашій державі безпосередньо. Таких рішень небагато, але серед них варто виділити наступні: «Дубецька та інші проти України» [4] (щодо забруднення екологічного середовища, спричиненого діяльністю збагачувальної фабрики), «Гримковська проти України» [5] (щодо побудови автомобільної дороги біля житлової вулиці) та «Дземюк проти України» [6] (щодо облаштування кладовища біля будинку заявника, що порушує його право на повагу до житла та приватного життя).

Аналізуючи вищезазначене, можна констатувати, що в Україні існує правова основа забезпечення екологічних прав громадян, але відсутній, на превеликий жаль, дієвий механізм їх захисту.

Щодо забезпечення екологічних прав людини в Республіці Польща. В ст. 74 Конституції Республіки Польща стосовно екологічної політики держави зазначено наступне: «Публічна влада проводить політику, що забезпечує екологічну безпеку сучасному і майбутнім поколінням. Охорона навколишнього середовища $є$ обов'язком органів державної влади. Кожен має право на інформацію про стан і охорону навколишнього середовища. Публічна влада підтримує дії громадян щодо охорони і поліпшення стану навколишнього середовища» [7]. Цікавим є те, що ні Закон Республіки Польща «Про охорону навколишнього природного середовища» [8] ні iї Конституція не мають чіткого закріплення екологічних прав громадян, як це зазначено у законодавстві України. Простежується тенденція, що в Польщі охорона навколишнього природного середовища $є$ однією 3 цінностей, якій найбільше приділяється увага 3 боку держави та громадян. Але натомість, екологічне право громадян Польщі на безпечне навколишнє 
середовище не $\epsilon$ чітко зазначеним і лише випливає із обов'язків держави забезпечувати теперішньому і наступним поколінням безпечне екологічне середовище.

В грудні 2018 року було проведено Саміт СОР24 в Катовиці (Республіка Польща). Саміт змусив задуматись над тим, як охорона навколишнього середовища пов'язана із правами людини. Було зазначено про необхідність більш широкого розгляду проблеми захисту навколишнього середовища [9]. Таким чином, в законодавстві Республіки Польща окремо не виділяють екологічні права, а лише пов'язують охорону довкілля із охороною прав, які гарантуються людині державою.

Аналізуючи вищевказене, можна зробити висновок, що в Республіці Польща, право людини на безпечне навколишнє середовище формулюється із обов'язку людини та держави забезпечувати охорону навколишнього природного середовища. Натомість в Україні навпаки: праву громадянина на безпечне для життя i здоров'я довкілля кореспондують обов'язки щодо забезпечення такого права.

Така невизначеність в законодавстві Республіки Польща екологічного права на безпечне навколишнє середовище не означає відсутність гарантування його державою. Але так як і в Україні, в Республіці Польща відсутнє організоване екологічне судочинство, а усі справи у сфері екології, здебільшого, присвячені питанню раціонального використання природних ресурсів.

Розвитку екологічного судочинства як в Республіці Польща, так і в Україні можуть допомогти самі громадяни держав, звертаючись до національних судів за захистом своїх екологічних прав та до ЄСПЛ, рішення якого сприятимуть більшому розумінню національних проблем у сфері захисту екологічних прав людини.

Отже, можна зробити наступні висновки, що дослідження проблеми екологічних прав людини $є$ однією із найактуальніших наукових дискусій. Їх реальне забезпечення та захист $\epsilon$ запорукою виходу суспільства на новий рівень співіснування 3 природою. На основі аналізу правового забезпечення екологічних прав громадян в Україні та Республіці Польща необхідно констатувати, що механізм правового забезпечення екологічних прав людини в Україні є більш розвиненим, ніж в Республіці Польща. Однак, Республіка Польща велику увагу приділяє охороні навколишнього середовища, наділяючи органи державної влади та громадян обов'язками щодо забезпечення охорони довкілля як важливої цінності. Право людини на безпечне навколишнє середовище у законодавстві Республіки Польща чітко не закріплене. Тому громадяни Республіки Польща, захищаючи свої екологічні права, 
насправді, не можуть посилатися на норми, де ці права зазначені, а можуть лише скаржитися на невиконання обов'язків держави чи інших громадян щодо забезпечення охорони довкілля.

У зв'язку з вищезазначеним, можна констатувати, що розвинені держави повинні закріплювати у своєму законодавстві право на безпечне навколишнє середовище та ряд пов'язаних екологічних прав, а також розвивати екологічне судочинство, адже майбутнє світу залежить від уміння людини співіснувати із природою. Суспільство невпинно розвивається і кожна людина заслуговує мати право, яке реалізує іiі інтерес на конкретному етапі його розвитку, а також дієвий механізм його забезпечення і захисту.

\section{Література:}

1. Антонюк У. В. Правова охорона довкілля в Польщі. Науковий вісник Херсонського державного університету. Серія: Юридичні науки. 2016. Вип. 2 (2). С. 7-10.

2. Конституція України: прийнята на п'ятій сесії Верховної Ради України 28 червня 1996 р. Відомості Верховної Ради Украӥни. 1996. № 30. Ст. 141.

3. Про охорону навколишнього природного середовища: Закон України від 25.06.1991. Відомості Верховної Ради Украӥни. 1991. № 41. Ст. 546.

4. Дубецька та інші проти України. Рішення Європейського суду з прав людини від 10.02.2011. URL: https://zakon.rada.gov.ua/laws/ show/974_689\#Text.

5. Гримковська проти України. Рішення Свропейського суду з прав людини від 21.07.2011. URL: https://zakon.rada.gov.ua/laws/ show/974_729\#Text.

6. Дземюк проти України. Рішення Свропейського суду з прав людини від 04.09.2014 URL: https://zakon.rada.gov.ua/laws/ show/974_a51\#Text.

7. Konstytucja Rzeczypospolitej Polskiej z dnia 2 kwietnia 1997 r. URL: https://www.sejm.gov.pl/prawo/konst/polski/kon1.htm.

8. Prawo ochrony środowiska: Prawo Polskie z dnia 27 kwietnia $2001 \mathrm{r}$. URL: https://isap.sejm.gov.pl/isap.nsf/download.xsp/WDU20010620627/ U/D20010627Lj.pdf.

9. Prawo do czystego środowiska jako prawo człowieka. URL: https://www.rpo.gov.pl/pl/content/panel/sesja-11-prawo-do-czystego\%C5\%9Brodowiska-jako-prawo-cz\%C5\%82owieka-blok-c. 